\title{
Balkan Border Crossings : First Annual of the Konitsa Summer School
}

\author{
Hakala, Emma
}

2013-11-28

Hakala , E 2013 , ' Balkan Border Crossings : First Annual of the Konitsa Summer School ' , Journal of Borderlands Studies , vol. 28 , no. 2 , pp. 275-276 . https://doi.org/10.1080/08865655.2013.854659

http://hdl.handle.net/10138/154842

https://doi.org/10.1080/08865655.2013.854659

acceptedVersion

Downloaded from Helda, University of Helsinki institutional repository.

This is an electronic reprint of the original article.

This reprint may differ from the original in pagination and typographic detail.

Please cite the original version. 
This article was downloaded by: [Emma Hakala]

On: 05 December 2013, At: 05: 42

Publisher: Routledge

Informa Ltd Registered in England and Wales Registered Number: 1072954 Registered

office: Mortimer House, 37-41 Mortimer Street, London W1T 3J H, UK

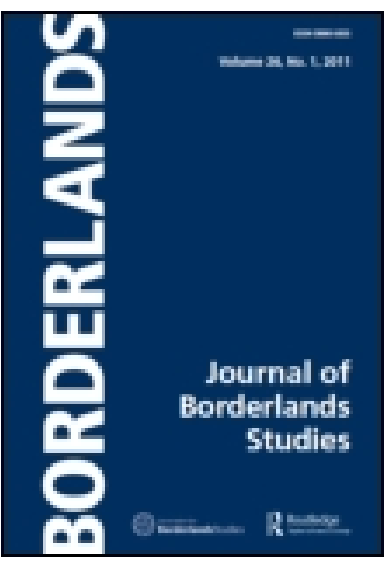

\title{
J ournal of Borderlands Studies
}

Publication details, including instructions for authors and subscription information: http:// www. tandfonline.com/loi/ rjbs20

\section{Balkan Border Crossings - First Annual of the Konitsa Summer School}

\author{
Emma Hakala PhD Candidate (M. Soc. Sci. ) \\ ${ }^{a}$ Aleksanteri Institute/ Faculty of Social Sciences, University \\ of Helsinki, PO Box 42 (Unioninkatu 33), Fl-00014 University of \\ Helsinki, Finland | +358 504151717 \\ Published online: 28 Nov 2013.
}

To cite this article: Emma Hakala PhD Candidate (M. Soc. Sci.) (2013) Balkan Border Crossings First Annual of the Konitsa Summer School, J ournal of Borderlands Studies, 28:2, 275-276, DOI: 10.1080/08865655.2013.854659

To link to this article: http:// dx.doi.org/ 10.1080/ 08865655.2013.854659

\section{PLEASE SCROLL DOWN FOR ARTICLE}

Taylor \& Francis makes every effort to ensure the accuracy of all the information (the "Content") contained in the publications on our platform. However, Taylor \& Francis, our agents, and our licensors make no representations or warranties whatsoever as to the accuracy, completeness, or suitability for any purpose of the Content. Any opinions and views expressed in this publication are the opinions and views of the authors, and are not the views of or endorsed by Taylor \& Francis. The accuracy of the Content should not be relied upon and should be independently verified with primary sources of information. Taylor and Francis shall not be liable for any losses, actions, claims, proceedings, demands, costs, expenses, damages, and other liabilities whatsoever or howsoever caused arising directly or indirectly in connection with, in relation to or arising out of the use of the Content.

This article may be used for research, teaching, and private study purposes. Any substantial or systematic reproduction, redistribution, reselling, loan, sub-licensing, systematic supply, or distribution in any form to anyone is expressly forbidden. Terms \& Conditions of access and use can be found at http://www.tandfonline.com/page/termsand-conditions 


\section{Balkan Border Crossings - First Annual of the Konitsa Summer School}

Vassilis Nitsiakos, Ioannis Manos, Georgios Agelopoulos, Aliki Angelidou, and Vassilis Dalkavoukis (eds.), Berlin: LIT Verlag, 2008.

\section{Reviewed by Emma Hakala, PhD Candidate (M. Soc.Sci.)*}

Emma Hakala is a PhD Candidate at the Aleksanteri Institute of the University of Helsinki, Finland. Her research focuses on the history of environmental cooperation, and she has been writing her dissertation on the role of international organizations in environmental projects in the Western Balkans since the end of the conflicts of the 1990s.

Border studies has considerably benefited from multi-disciplinary perspectives but this does not necessarily make the job of conceptualization and research in the field any less complicated. The need to combine variable approaches is a struggle especially for young researchers who, at the beginning of their careers, may find it difficult to incorporate insights from different fields. The Border Crossings Network, established in cooperation by a number of Balkan universities, seeks to address this problem, in particular through the organization of the Konitsa Summer School in Anthropology, Ethnography and Comparative Folklore of the Balkans that has also inspired "Balkan Border Crossings_-First Annual of the Konitsa Summer School".

Contributors include senior lecturers and researchers participating in the summer school, but most significantly the book has offered a medium to graduate students. The articles vary considerably in topics while still demonstrating interconnections between different fields. Many contributors in one way or another echo the universality of political-religious relations as the foundation of societies. Maurice Godelier supports this view in his compelling introductory paper that draws on a wide geographic and cultural range of examples.

The topics of other senior lecturers are more regionally focused. Jane K. Cowan explores the processes of creating national subjects under the Ottoman influence in the south of the Balkans in the first decades of the $21^{\text {st }}$ century. As one of the few historical pieces in the volume, it also usefully works as a background to the general topic of the book. Aliki Angelidou, on the other hand, discusses the post-socialist transformation through economic anthropology in a study of cooperatives in the Bulgarian countryside in the 1990s. He looks beyond national policies and officials to emphasize the role of local actors as active participants in the processes that shape social structures.

Rajko Mursik takes Lacan's theory of otherness as a starting point as he discusses the ways in which symbolism in different styles of popular music affects Balkan identity formation. He points out the case of Slovenia, where the Balkans is essentially seen as "the other," while a stereotyped version of the concept has become an outlet for expressing a sense of Balkan-ness and even Yugo-nostalgia in a commonly accepted context. Fontini Tsibiridou also touches upon the issue of otherness, exploring the ways in which Muslim womanhood and citizenship is built by the women themselves as self-reflective actors. She goes on to propose a number of approaches - emphasizing reflexivity, cultural critique and local actors - to be used in further research on Muslim Oriental womanhood, that can also be seen as beneficial for anthropological research more generally. Meanwhile, Evgenia Krasteva-Blagoeva and Goran Blagoev provide a different perspective on Muslim identity in their article on the Pomak minority of Bulgaria. Again challenging traditional cultural stereotypes they argue that while religion is the primary element defining a distinctive Pomak identity, it by no means excludes the possibility of openness towards globalization and cross-border influences.

* Aleksanteri Institute/Faculty of Social Sciences, University of Helsinki, PO Box 42 (Unioninkatu 33), FI-00014 University of Helsinki, Finland | +358504151717 | emma.hakala@helsinki.fi 
One of the aims of the summer school was to offer the graduate students a chance to do fieldwork on location, meaning that their contributions are focused on the Greek-Albanian border area. These studies explore different aspects of life on both sides of the border, mainly from an anthropological point of view. For example, Katarina Bielenin has looked at the co-existence of different ethnic communities in the Albanian town of Leskovac while Nebi Bardhoshi and Olsi Lelaj focus on the way the Albanian identity is "negotiated" in the same town. Meanwhile, Gerda Dalipaj uses case studies to explore the lives of Albanian women who have moved to the Greek town of Konitsa and suggests "identity transformation" as a more fitting term to describe the particular process they go through rather than the traditional "identity renegotiation." In the only article reaching beyond this geographical area, Larissa Vetters has observed local community offices in the city of Mostar in Bosnia Herzegovina, exploring the interactions and encounters that take place between international administrators, local officials and citizens in a particularly multi-ethnic setting.

Eckehard Pistrick again builds upon the concept of otherness in an article on the role of multipart singing in formulating regional identities in the Albanian borderland, seeing it as a metaphor for the continuous process of identity negotiation. In addition, Antonio M. Pusceddu touches upon similar themes in his study of the ways in which local oral history of the Greek-Albanian borderland is turned into accepted "history," convincingly arguing that literacy has an important role in the process. Meanwhile, two articles focus very concretely on the border itself: Ioannis N. Drinis' historically inspired discussion on the different significations given to the Greek-Albanian border over the years, and Fenia Tsobanopoulou's study on the Konitsa border guards, whom she aptly describes as acrobats between two cultures.

Many of the studies have been developed specifically for the summer school and are therefore based on data gathered during a restricted period of time. This inevitably limits the depth of analysis, as some of the writers themselves observe-some indeed aim to write essays rather than articles. The second part of the book is therefore less likely to provide elaborately argued insights or new theoretical approaches, but it does present the results of a process that must have been extremely educational to the young researchers themselves and that may well yield fresh new ideas to build upon.

The book compellingly shows the variety of topics encountered in the study of a single, geographically narrow borderland region. With its range of perspectives the book is likely to be interesting from a number of disciplinary points of view. Inevitably, there is a degree of inconsistency, and a more elaborate introduction would have been beneficial in order to better trace the idea of border crossings as the unifying theme of the book. However, it adeptly serves its purpose at giving doctoral students tools for their research in borderlands studies while addressing a regional need for new perspectives on the topic. 